NBER WORKING PAPER SERIES

\title{
THE CAUSES AND CONSEQUENCES \\ OF RATE REGULATION IN THE \\ AUTO INSURANCE INDUSTRY
}

Dwight M. Jaffee

Thomas Russell

Working Paper 5245

\author{
NATIONAL BUREAU OF ECONOMIC RESEARCH \\ 1050 Massachusetts Avenue \\ Cambridge, MA 02138 \\ September 1995
}

This paper was prepared as part of the NBER Study on Property Casualty Insurance and was presented at the NBER Study Conference. Any opinions expressed are those of the authors and not those of the National Bureau of Economic Research.

(C) 1995 by Dwight M. Jaffee and Thomas Russell. All rights reserved. Short sections of text, not to exceed two paragraphs, may be quoted without explicit permission provided that full credit, including $\odot$ notice, is given to the source. 


\title{
THE CAUSES AND CONSEQUENCES \\ OF RATE REGULATION IN THE \\ AUTO INSURANCE INDUSTRY
}

\begin{abstract}
This paper examines various explanations for the increase in the degree of regulation of the auto insurance industry in the last ten years. Using cross section data for the State of California, the paper confirms earlier findings for the State of Massachusetts that the demand for auto insurance is highly price elastic. This implies that regulation induced price rollbacks (such as those mandated by California's popular initiative Proposition 103) have significant welfare effects. We explain the increase in regulation in two ways:

a) As an attempt to lower rates to deal with the problem of the uninsured motorist.

b) More fundamentally as a response to the perceived lack of fairness of the sharp increase in premiums in the 1980 s.

This perception of lack of fairness arises because, although auto insurance costs rose sharply in the 1980s, most buyers of auto insurance have no claims in any ten year period. Thus most buyers have only last year's premium as a reference point with which to judge the fairness of this year's premium.

The hypothesis that the increase in regulation is driven by a perception of unfairness is tested by analyzing the cross county voting pattern on Proposition 103. Voting in favor of price regulation is positively correlated with the level of insurance premium. This result is consistent both with the view that voting behavior is based on self interest and with the view that the increased demand for regulation is driven by concerns that the large disparity in premiums across counties is unfair.
\end{abstract}

Dwight M. Jaffee

Haas School of Business

University of California, Berkeley

Berkeley, CA 94720
Thomas Russell

Leavey School of Business

Santa Clara University

Santa Clara, CA 95053 


\section{INTRODUCTION ${ }^{1}$}

The extent and detail of state regulatory control over the auto insurance industry has increased markedly in the last ten years. ${ }^{2}$ In many cases, this change in the regulatory environment has come about as a consequence of well-organized, grass roots, consumer activism. The passage of California's Proposition 103, a voter initiative which, among other provisions, enacted a roll-back of insurance premium rates and a limit on the actuarial information which could be used in setting these rates, is a case in point. Proposition 103, however, is by no means unique; following its passage in November 1988, 44 states considered similar regulatory changes, and similar legislation passed in the states of Nevada, New Jersey, South Carolina, and Pennsylvania (see Rosenfield [1991]).

These "populist" moves to regulate auto insurance rates are based on the view that the insurance industry uses "unfair and discriminatory pricing practices". 3 Two forms of regulation have been imposed. One form restricts the factors that insurance companies are allowed to use in defining risk categories --this is called rate compression. A second form restricts either the overall level of premiums or the rates applied to particular categories -this is called rate suppression; see Harrington [1992] for a discussion of this term. We use the term rate regulation to refer to compression and suppression together.

Rate compression is illustrated by California's Proposition 103 which stipulates that, without the additional approval of the insurance commissioner, passenger automobile insurance rates may apply only the following three factors:

(1) the driver's safety record,

(2) the number of miles driven annually,

(3) the number of years of driving experience. 
Such characteristics as the driver's place of residence, age, sex, and marital status could no longer be used without the approval of the insurance commissioner. These factors were frequently used by insurance companies prior to the passage of Proposition $103 .{ }^{4}$

Rate suppression is used in Massachusetts, where premiums in many categories are explicitly set below the actuarial cost--a system called tempering. Blackmon and Zeckhauser [1991] report that in Massachusetts, expected costs vary across drivers by a factor of 4.4, but premiums vary by only a factor of 3 . Expected costs vary across territories by a factor of 2.7 , but premiums vary by only a factor of 2 .

Insurance companies, of course, have an incentive to reject customers who must be charged suppressed rates. Since auto insurance is mandatory in all states, rejected customers still need insurance, which is generally provided through assigned risk pools. Drivers who are denied auto policies are placed in the assigned risk pool, and charged a premium that may be below the actuarial costs. Each auto insurance company in the state is then required to take a share of the assigned risk pool equal to its share of the overall market. ${ }^{5}$

Standard welfare economics provides no simple explanation for regulatory pressures in this market. There are two factors which may work in the direction of welfare enhancement. First, in a world of imperfect information and costly sorting, rate compression could work to curtail a tendency to form (socially) too many risk categories. Second, by lowering premiums, rate suppression could induce previously uninsured drivers to purchase coverage, thus eliminating externalities associated with uninsured motorists. On the other hand, as with any cross-subsidization scheıne, there are obvious welfare losses associated with rate regulation. Drivers who are charged premiums above their true costs will underconsume 
driving, auto insurance, or both, and vice versa. The net welfare effect of regulation is thus far from clear.

Given this, the question arises why the auto insurance industry has emerged as a primary target for increased regulation. The main goal of this paper is to try to answer this question by linking the possible sources and consequences of rate regulation. The agenda of the paper is the following. Section 2 develops the economics of auto insurance for an unregulated industry. Section 3 outlines the details of Proposition 103. Section 4 explores the various sources of demand for rate regulation, including the populist sentiments already mentioned. Section 5 looks at the economic effects of rate regulation. Section 6 provides empirical results that evaluate the welfare effects of auto insurance regulation. Section 7 provides corresponding empirical results concerning the voting record on Proposition 103. Section 8 provides conclusions and topics for future consideration.

\section{THE STRUCTURE OF AN UNREGULATED INSURANCE INDUSTRY}

To understand the reasons for the success of the pro-regulation movement and to provide a benchmark from which to evaluate the consequences of regulation, it is useful to examine how the auto insurance industry in California operated before the passage of Proposition 103. Even before Proposition 103, the State Insurance Commissioner had the duty to ensure that insurance rates were "neither excessive nor inadequate", but, as noted by Sugarman [1990], this price control authority was rarely used. Once the Commissioner found that the market was competitive, the inquiry into excessive rates ended. Rather remarkably (at least for economists), Proposition 103 expressly states that with regard to excessive rates, "no consideration shall be given to the degree of competition". 6 Assume, then, that prior to 
the passage of Proposition 103, auto insurance in the State of California was, in essence, an unregulated competitive industry. How does such an industry operate?

In the first wave of economic analysis of this question, Arrow [1963], Borch [1990], and Malinvaud [1972] showed that if sellers of insurance have full information regarding the risk class of each insured, then a competitive industry, given zero administrative costs and a large number of risks in each risk class, would offer an array of insurance contracts, one for each risk class, the premium on each contract being set so that each contract earned zero profits on average. Buyers of insurance, given that they act to maximize expected utility, would then fully insure at the actuarially fair odds appropriate to their risk class.

This early analysis was followed by the seminal contribution of Rothschild and Stiglitz [1976], who noted that the assumption of full information regarding individual risk does not hold in many insurance markets. Often the buyers of insurance have more information regarding the risk of loss than do the sellers. In this case Rothschild and Stiglitz showed that the resulting adverse selection may be so strong that it prevents the market from having an equilibrium (in the Nash sense). When an equilibrium does exist it will separate the high and low risk buyers, with the low risk buyers facing quantity rationing.

The equilibrium concept was subsequently refined by Miyazaki [1977], Riley [1979], and Wilson [1977], who assumed that sellers anticipate the reactions of other sellers when adding or deleting new contracts. These models generate a broader set of conditions under which equilibrium may exist, and the equilibrium structure may have either separating contracts, as in Rothschild/Stiglitz, or a single pooled contract for all buyers.

These authors were all concerned with characterizing equilibrium in a one-period model of the industry. When the industry deals with customers in a multiperiod setting, there 
are a number of additional methods for dealing with the problem of adverse selection. Cooper and Hayes [1987], for example, noted that it is possible to design a contract pair, (a single period contract and a multiperiod contract in which the premium falls over time), so that only low risk individuals buy the multiperiod contract. Thus, this contract pair solves the adverse selection problem.

Kunreuther and Pauly [1985], on the other hand, note that over time an insurance company obtains private information regarding a driver's riskiness. Insurance companies may then underprice policies in the first year of a contract, because this provides them the option to renew good customers at favorable rates in later years. In the following years, the companies may increase premiums even to those drivers whose record shows them to be of low risk, given the transaction costs these drivers would face in switching companies. This model thus predicts the opposite dynamic pricing structure from that predicted by Cooper and Hayes, since here the insured faces a premium structure which is predicted to rise over time. See D'Arcy and Doherty [1990] for a fuller discussion of this issue.

The existence of equilibrium is also made problematic by the presence of moral hazard. In a monopolistic setting, multi-period contracts designed by Radner [1985] to deal with moral hazard in labor markets and extended to insurance markets by Rubinstein and Yaari [1983] could deal with this problem. However, these contracts cannot be offered competitively. The issues of adverse selection and moral hazard are surveyed in Dionne and Doherty [1992].

Relative to the large body of theoretical work giving possible equilibrium structures for this industry, the amount of empirical work describing actual equilibrium is rather small. Dahlby [1983] provides evidence of adverse selection, and D'Arcy and Doherty [1990] 
provide evidence that seasoned customers generate quasi-rents. But many of the features discussed in the theoretical literature, e.g., quantity rationing of good risks, multiple-year contracts, price increases to good customers, do not seem to be present in actual insurance markets and certainly do not seem to be any part of the rhetoric of those who wish to limit market competition.

On the other hand, the industry does have a number of features which, as yet, have not received much attention from theorists. Since these features may be relevant to the industry's vulnerability to regulatory attacks, we now set out a stylized structure designed to capture the essence of the way in which the industry actually operated before regulation. We concentrate on four features of this stylized equilibrium.

1. Recognizing the fact that individuals belong to different risk classes, each firm in the industry set up a large number of information cells, and collected data on the loss experience in each cell. These cells were largely standardized across the industry, with little variation from firm to firm. (An example of a cell might be a 50 year old married man who drives a 1990 Volvo and lives in San Francisco.) The standardization of cells was coordinated through an industry data collection agency (such as the Insurance Service Office) and presumably arose as a consequence of economies of scale in data collection and analysis.

Industry standardization of the classification scheme can be motivated by at least two factors. First, firms that attempt to introduce new rating classes will face the costs of obtaining and applying the new information. But they are unlikely to obtain a competitive edge from the innovation, since other firms can costlessly observe and apply the innovator's premium structure. Second, standardization may be an important mechanism through which 
the industry helps protect itself against individual firms offering new contracts which attempt to "cream-skim" customers.

2. Since each cell has an associated loss experience, the insurance company can now statistically determine a loss relative for each cell, and from this can determine a cell-specific premium. (A useful summary of the statistical methods used to determine loss relatives is given by Jee [1989]). It is clear, however, that within any cell there are individuals whose risk is misclassified in the sense that their true risk of accident lies above or below the estimated risk for their cell. This was treated by each firm as a fact of life. In particular, direct quantity rationing was not used to induce individuals to self-select the appropriate risk cell. $^{7}$

3. Although it is possible to associate a competitive risk premium with each cell, in fact firms did not write an insurance contract for each cell. Even before regulation of prices, firms in the insurance industry engaged in a system of voluntary rationing and "risk tiering". It is easiest to describe how this system worked by example.

Suppose that an individual applied for auto insurance at a major automobile insurance company. Three events could occur:

a. If the individual fell into a high enough loss ratio cell (say because of multiple moving violations) the insurance company simply refused to write a policy, and instead placed the individual in the involuntary "assigned risk" pool.

b. If the individual fell into a cell with a loss ratio below that which led to outright rejection of the risk, but was still at the high end of the loss ratio (say because of one moving violation) the insurance company would not write a policy in its own name, but would issue a 
policy through a wholly owned subsidiary which only handled high risk drivers. This tier of insurance is called non-standard insurance.

c. If the individual fell into a low enough risk cell, the insurance company would then write a policy in its own name. This is called standard insurance.

The existence of this three tier structure is not easy to understand in terms of standard economic theory. "Risk tiering", however, has been observed in other industries (for example, banks do not make high risk consumer loans) and in the case of credit markets Jaffee and Russell [1993] argue that "risk tiering" is a market response to concerns of fairness. We will examine this question of fairness later when we examine the reasons for regulation.

4. Insurance companies, in general, did not issue multi-year contracts. There was some limited experience rating, good drivers in some cases being given discounts, but insurance contracts offering a menu of premium terms based on the length of the contract do not seem to have been offered.

\section{REGULATION IN CALIFORNIA: PROPOSITION 103}

Proposition 103 was (narrowly) passed to regulate an industry with the above structure. The immediate impetus for the initiative seems to have been two-fold, partly concern with the large rate of premium increases in the years prior to 1988 , and partly concern with the large disparity in premia among individuals with prima facie similar risk characteristics. (For example, individuals living on opposite sides of a street could have auto premia which differed by a factor of 2.0 ; see Williams [1992].) 
With respect to the industry equilibrium, Proposition 103 required the following changes:

a. All insurance rates were to be rolled back $20 \%$ from the rates holding on November 8, 1987.

b. All future rate changes were to be approved by the Insurance Commissioner who was now to be elected, not appointed.

c. Only very specific factors could be used in setting risk classes. These were to be (in order of importance):

i. the insured's driving record

ii. the annual number of miles driven

iii. the years of driving experience

Other factors could be used, if approved, but less weight must be given than to the first three factors.

d. Insurance companies were required to accept all "good drivers" who applied for insurance, where "good driver" was defined as having no more than one moving violation in the last 3 years. In addition all "good drivers" were to be offered a "good driver" discount.

With many of these provisions now in place, it is no longer possible to view the insurance industry in California as providing a competitive solution to the problem of risk allocation. What was it about the competitive solution outlined above which so upset the California voters? We turn now to an analysis of the possible causes of insurance market regulation. 


\section{WHY INSURANCE CONTRACTS PROVOKE REGULATORY ACTION}

There are many possiole explanations for why auto insurance has become the target of consumer-based regulatory movements. Perceived self-interest, for example, may lead to a call for roll-backs and rate ceilings, since consumers may think that premium ceilings can create lower prices with an unchanged supply.

Why insurance, though, and not, say, beer? The absence of a grass-roots consumer movement calling for a roll back in the price of beer (and most other goods) suggests that consumers recognize that the deadweight costs of price regulation generally exceed the benefits of such regulation. It thus, remains an important question why automobile insurance has been singled out for such attention.

Our analysis considers three main sets of explanations for consumer initiatives that create rate regulation. The first set uses considerations of distributional equity to motivate rate regulation as a means of achieving risk sharing or income redistribution for risk averse individuals. The second set is based on the welfare enhancement that may arise from rate regulation in insurance models such as the type developed by Rothschild and Stiglitz [1976] and its extensions. The third set is based on concepts of fairness in response to the perception of unfair and discriminatory practices in insurance premium setting.

\section{A Distributional Equity}

In their recent study, Blackmon and Zeckhauser [1991] (BZ) consider motives based on distributional equity which might cause risk averse individuals to accept the deadweight losses created by rate regulation. We summarize here their arguments concerning the risk sharing and income redistribution motives that would be relevant to risk averse individuals. 
Risk Sharing

Suppose, for simplicity, that each driver's risk of an auto accident belongs to one of two categories, $P_{H}$ a high risk class, or $P_{L}$ a low risk class. At some initial date $(t=0)$, drivers are assumed to be in a Rawlsian state of ignorance about their true class. At a later date $(t=1)$, insurance markets open and each driver's risk is revealed to both the driver and the market. In the absence of dead weight loss, all risk averse drivers would vote at $t=0$ to force insurance firms at $\mathrm{t}=1$ to charge only a single premium rate, reflecting the average risk of the population.

Using a similar argument, drivers might resist any form of categorization because it introduces a classification risk. That is, consumers may prefer to have premiums based on the community's average risk, instead of entering what they may think of as a classification lottery to determine whether they are to be treated as high risk or low risk. The argument is particularly forceful if consumers do not know their risk class initially, but are provided an estimate of it through the categorization process.

BZ estimate the dead weight loss and compute the coefficient of risk aversion required to cause individuals to support single-class contracts in the face of this loss. They reject the risk-class uncertainty hypothesis on the basis of the unrealistically high risk aversion coefficient which is required to generate the amount of tempering observed in Massachusetts. However, we should recognize that Massachusetts has perhaps the greatest degree of tempering of auto insurance rates in the United States. Also BZ estimate a relatively high price elasticity of demand, which magnifies the deadweight loss of rate regulation.

On the other hand, the existence of bans on the use of certain immutable characteristics, for example, gender, in the setting of auto insurance rates, provides support 
for the Rawlsian argument. In a Rawlsian state of ignorance, individuals would not know their gender, and the adoption of this moral reference point would explain their desire that insurance rates be blind to immutable characteristics.

Income Redistribution. Individuals may use rate suppression as a means to redistribute income. Obviously, if insurance is offered at the same rate to individuals with objectivity different risks of accident, the high risk individuals will be subsidized by the low risk individuals. This in turn will generate income distribution from low risk (presumably high income) to high risk (presumably low income) drivers. Citizens could desire this income redistribution for its own sake.

$\mathrm{BZ}$, however, again reject the income redistribution hypothesis on the basis of the high level of dead-weight loss. It should be noted that in Massachusetts rate regulation was imposed by the Insurance Commissioner, who presumably was responsible for evaluating the tradeoff between the income distribution benefits and the deadweight costs. In the context of voter initiative states such as California, however, it is not clear the extent to which this deadweight loss enters the mind of individual voters when they pull the ballot lever.

\section{B Welfare Enhancement}

It is possible that the move to regulate the insurance market was motivated by a desire to remove observed inefficiencies in the unregulated market. The consumer activists who pressed for regulation, however, did not document such inefficiencies, instead arguing that regulation was necessary to improve the fairness of the pricing structure.

Of course, it is still pcssible that as a "side-effect" of fairness-led reform, the market could become more efficient. Since welfare enhancement was not the primary motive for 
regulation, however, we postpone a discussion of the efficiency aspects of rate regulation to the section dealing with the consequences of regulation. We turn now to the central argument used by the pro-regulation camp, the view that auto insurance rates were unfair.

\section{C Fairness $^{8}$}

Kahneman, Knetsch, and Thaler [1986] have documented that consumers have a well developed sense of when a price is or is not fair. As a consequence, these authors argue that considerations of fairness will limit price dispersion when the price dispersion has no obvious basis in differential costs.

This argument clearly has relevance to the types of regulation which we observe in auto insurance. Suppose perceived costs to a buyer of insurance are gauged by actual accident costs. Since most insurance buyers have no accidents in any given year, most buyers will perceive themselves as imposing the same costs on insurance companies. Yet drivers in different risk classes may face very different prices.

For example, in Los Angeles county, in the 5 year period 1983-1988, the frequency of claims for bodily injury liability was 2.4 times the statewide average for these claims. ${ }^{9}$ Yet, in this 5 year period, the actual total of incurred claims in L.A. was 71,890 on an "installed base" of 1,464,079 autos. Thus $95 \%$ of all insured automobiles in Los Angeles County had no claims in 5 years. Nevertheless, these Los Angeles county drivers faced insurance premiums about 2.4 times as high as the state average.

The inherent concerns for fairness raised by the pricing structure of a competitive insurance industry are exacerbated by the following considerations: 
1. In the years before Proposition 103, private passenger auto insurance rates in the state grew very fast, see below (National Association of Insurance Commissioners $[1988]^{10}$

$\begin{array}{ll}\text { Year } & \text { Growth Rate of Auto Insurance Premia } \\ & \\ 1982 & +9 \% \\ 1983 & +8 \% \\ 1984 & +12 \% \\ 1985 & +20 \% \\ 1986 & +22 \% \\ 1987 & +13 \% \\ 1988 & +13 \%\end{array}$

To the extent that consumers use a historical premium as a reference point for calculating a fair premium, and again remembering that most drivers would have no claims in this 6 year period, this doubling of premia seems likely to contribute to the sense of unfairness.

2. Returning to the question of fairness across risk categories, in any risk cell there will be some drivers who are misclassified simply because statistical procedures are designed to classify risk on average. Again remembering that a small difference in loss relative, say 1.2 rather than 1 , translates into a $20 \%$ difference in premium, misclassified drivers may well feel aggrieved.

3. In addition to objectively legitimate concerns about misclassification, there is also the Lake Wobegone effect. Recall that in mythical lake Wobegone every student was above average. If every driver believes himself to be above average, he will vote to be placed in a lower risk pool, and this can lead to rate compression.

4. Classification based on immutable characteristics or characteristics which are correlated but not causative will also increase concern. Individuals may feel that immutable 
characteristics such as gender ought not to be used as criteria for price discrimination.

Similarly, when the classification factor is correlative but not causative, for example zip code as opposed to years of driving experience, concerns for fairness may be heightened.

Further evidence on consumer's views of the fairness of insurance premiums is given by a Gallup Organization poll of 1,000 consumers conducted in 1990 . The results of this poll are shown in Table 1.

As can be seen, in this poll, which focussed specifically on the fairness of premiums, $65 \%$ of consumers thought that property/casualty insurance companies overcharged, and $61 \%$ of consumers thought that property/casualty insurance companies were more profitable than other industries. This suggests that issues of fairness in the Kahneman, Knetsch, Thaler [1986] sense could easily contribute to an explanation of both the roll-back and rate compression features of Proposition 103. Whatever the motivation, of course, once these regulations are in place they will have more standard welfare implications. We turn now to an examination of these welfare effects.

\section{RATE REGULATION, EFFICIENCY, AND WELFARE}

The welfare economics literature for insurance markets has expanded greatly in recent years, partly reflecting fundamental advances in information economics, and partly reflecting attempts to apply economic analysis to the current political issues in insurance markets. Our primary goal is to identify the results that are applicable to auto insurance markets.

In most competitive industries ${ }^{11}$, regulation of prices and/or quantities reduces efficiency. The auto insurance industry, however, has at least two special features requiring special attention. 
1. By its nature, the automobile insurance industry uses actuarial information to sort individuals into risk classes. Since Spence [1973], it has been known that private and social incentives to sort do not always coincide. There is thus room for rate compression to be welfare enhancing.

2. In many states a large number of drivers do not purchase auto insurance. (For example, some estimates suggest that as many as $30 \%$ of the drivers in California do not insure). If price rollbacks induce non-insured motorists to buy insurance, rate suppression may be welfare enhancing (see Smith and Wright [1992]). We now discuss each of these cases in turn.

\section{A Categorization in Auto Insurance Markets}

There is now an extensive literature dealing with the welfare economics of risk classification in insurance markets. Important contributions include Bond and Crocker [1991], Crocker and Snow [1986], Hoy [1989], Puelz and Kemmsies [1993], and Rea [1992]. There are also excellent summaries by Borenstein [1989] and Harrington [1993].

Rather than discuss this literature in detail, we simply state the fundamental conclusion. In a competitive market, the decision whether or not to introduce a new risk class is based solely on a calculation of the costs and benefits to the potential members of this new class. A proper accounting for social welfare, however, should take into account not just the welfare of the members of the new class, but also the welfare of the remainder of the population who do not join the new class. It is very easy, see Borenstein [1989], to construct examples of costly sorting in which introducing a new risk class increases the welfare of its members slightly (after they pay the cost of the sorting), but decreases substantially the welfare of the rest of society so that net social welfare is reduced. 
In the case of costless sorting, however (and this may be the more common case in auto insurance), restrictions on categories will normally reduce welfare. The magnitude of this welfare loss is positively related to the level of the premium elasticities.

In the next section we provide estimates of these elasticities.

\section{B Uninsured Motorists}

The presence of uninsured drivers generates an externality which can be corrected by appropriate intervention. To see this we present here a simplified version of the models of Keeton and Kwerel [1984] and Smith and Wright [1992] in which a competitive market equilibrium with uninsured motorists is Pareto dominated by a regulated market with appropriate income transfers.

Suppose that in a group of drivers the probability of an accident is $\pi$, and that when an accident occurs the total damage in dollars is $2 \mathrm{~L}, \mathrm{~L}$ to each driver. Suppose that the legal system assigns $100 \%$ fault to one of the drivers in every accident, and that in this case the driver at fault is responsible for the total loss (2L) up to the value of initial wealth, W. Assume that the probability that any given driver will be involved in an accident in which he is at fault is $\pi / 2$.

The actuarially fair (collision) insurance premium for each driver is thus $\pi / 2$ dollars per dollar of insurance. Expected utility maximizing drivers with sufficient wealth will fully insure by purchasing $2 \mathbf{L}$ of collision insurance at this premium. If all drivers fully insure the resulting equilibrium is Pareto Efficient.

Suppose, however, that drivers fall into two classes, based on initial wealth. Assume that $\theta \%$ of the population have a level of initial wealth, $\mathrm{W}_{\text {low }}$, which is such that it is 
expected utility maximizing to purchase zero collision insurance. Let the remaining (1- $\theta) \%$ have a wealth level $W_{\text {high }}$, which is such that they fully insure at a fair premium.

The presence of uninsured motorists sets up a demand for a new form of insurance which pays in the event that a driver is involved in an accident in which an uninsured motorist is at fault. Assuming that the probability that an accident between uninsured and an insured motorist only reflects the proportions of these two types in the total population, the actuarially fair premium for this uninsured motorist coverage is clearly $\theta \pi / 2$ per dollar of insurance. Drivers who are rich enough to fully insure will fully insure this risk too, but in this case they will buy coverage $L$, the value of their own loss.

Market equilibrium in this case has high income drivers paying a premium of $\pi \mathrm{L}$ for full collision insurance and $\theta(\pi / 2) \mathrm{L}$ for uninsured motorist insurance, and low income drivers buying zero insurance of either type.

To generate a Pareto improvement on this equilibrium, suppose we require each uninsured driver to buy full collision insurance at a cost of $\pi$ L. Note that if each uninsured motorist were risk neutral, the income transfer necessary to compensate for purchasing full collision insurance would be:

$$
\pi \mathrm{L}-[(\pi / 2) \mathrm{L}+\theta(\pi / 2) \mathrm{L}]=(1-\theta)(\pi / 2) \mathrm{L}
$$

The first term in the square bracket is the uninsured motorist's own expected collision loss when the accident is his own fault. The second term is the expected loss to an uninsured driver of being in an accident caused by another uninsured driver. We subtract these terms since they are no longer borne by an uninsured motorist if he fully insures.

Now suppose we tax each fully insured motorist $\theta(\pi / 2) \mathrm{L}$, the cost of uninsured motorist coverage. Since insured motorists make up $(1-\theta) \%$ of the population, this tax would 
enable us to give each uninsured motorist (with uninsured motorists making up $\theta$ percent of the population) an income transfer of $(1-\theta) \theta(\pi / 2) \mathrm{L} / \theta=(1-\theta)(\pi / 2) \mathrm{L}$. As we have just seen, however, this is precisely the amount needed to compensate a risk neutral uninsured motorist for buying full collision coverage. A fortiori, if the uninsured motorist is risk averse we could give him less income and still leave him as well off as when he was uninsured.

Furthermore, once the uninsured motorists buy full coverage there is no reason for the insured drivers to buy $\theta(\pi / 2) \mathrm{L}$ of uninsured motorist insurance. Thus this income transfer leaves the rich drivers as well off as before and increases the welfare of the poor drivers, so the scheme is Pareto improving. ${ }^{12}$ This, of course, merely demonstrates the possibility of a welfare improvement. Proposition 103 did not require an income transfer from the insured to the uninsured. Indeed the retroactive premium rollback is more directly a transfer of income from the stockholders of the insurance companies to those already buying insurance.

To this extent the price rollbacks of Proposition 103 seem more consistent with explanations based on fairness rather than with explanations based on efficiency. Nevertheless, the possibility remains open to design a cross subsidization scheme which causes all drivers to fully insure, and this would be welfare enhancing. In designing such a scheme it is again crucial to know the value of the elasticity of demand for insurance.

\section{C Rate Suppression}

In discussing categorization, it was assumed that insurance firms were allowed to charge whatever premiums they desire for a given category. Only the factors available for categorization were regulated. Now we consider matters the other way around. We take as given the available categories, but consider what happens if regulations impose ceilings on the premiums charged certain categories. 
If the industry is competitive, as we have been assuming, and no restrictions are placed on the categories, then insurance firms should refuse to write policies for the categories with suppressed prices. In other words, we should observe that policies are granted to all customers in categories where rates are not suppressed. We should also observe that policies are granted to no customers in categories where rates are suppressed.

The experience in California sheds light on the issue of rate suppression. One of the features of Proposition 103 is that risk rating of bad drivers is to be encouraged, suggesting that firms should be able to price this risk fully and then provide insurance to these customers. However, many companies have opted not to provide insurance to "unsafe drivers". This would suggest either that the companies believe that the premiums for this category are likely to be suppressed or that they are reluctant to file rates that consumer may consider to be unfair.

The experience in Massachusetts also sheds light on the issue of rate suppression. In Massachusetts, all rates are regulated with an explicit degree of tempering. We would expect to find no voluntary policies in the under-priced cells, and no rejections in the over-priced cells. In fact, as reported by Blackmon and Zeckhauser [1991], many cells feature partial acceptance and partial rejection. This suggests that the firms are using factors not included in the standard cell structure, perhaps including factors that were otherwise prohibited.

Rate suppression leads to a form of insurance rationing, comparable in some respects to credit rationing in the loan market. Auto insurance, however, is mandatory, and therefore the government must ensure that all drivers can obtain coverage. This creates the assigned risk pools, to which firms send the drivers whom they have rejected for insurance. 
In many ways, the assigned risk pool represents a very peculiar system. First, when the assigned risk pool premiums are suppressed, the plan subsidizes the objectively worst risks among drivers. What basis can there be for giving this group subsidies? Second, when the assigned risk pool premiums are not suppressed, as is increasingly the case, there should be little need for an assigned risk pool. In a competitive market, the voluntary insurance companies should be serving these customers.

We might expect rate suppression to create additional effects in terms of industry exit. Exit appears to occur only in the most egregious cases, and even then in limited amounts; for example, in Massachusetts, Blackmon and Zeckhauser report that $18 \%$ of the insurance firms left the state. There are reasons, however, why exit may not occur, including the expectation that regulation is temporary or that the industry is earning quasi rents.

We might also expect rate suppression to create reductions in quality. Quality reductions, however, are not widely evident, perhaps because other factors such as reputation, fear of law suits, and expectations that lower quality will create further pressure for lower premiums, all mitigate the incentive for lower quality (see Harrington [1992]).

\section{THE WELFARE EFFECTS OF AUTO INSURANCE: EMPIRICAL EVIDENCE}

Rate regulations influence welfare by distorting the relationship between premiums and costs. This causes individuals to drive too much (or too little) and/or to buy too much (or too little) auto insurance. The size of this welfare loss depends on two elasticities, the elasticity of the demand for autonnobiles, and, given that a car has been purchased, the demand for insurance. In this part, we develop estimates for these elasticities. 


\section{A Blackmon and Zeckhauser Estimates}

In some states, the distinction between the drive/not drive decision and the insure/not insure decision is of little consequence since the percentage of uninsured motorists is quite small. In Massachusetts, for example, less than 6\% of motorists drive insured (see Table 2). Therefore, Blackmon and Zeckhauser [1991] (BZ), in their study of the welfare costs of regulation in Massachusetts, calculate the deadweight loss by estimating the demand for insured vehicles. The number of insured cars per household $I_{h}$ is regressed against household income $Y_{h}$, auto insurance premiums $P$, and household density $D$ (a measure of congestion costs). The observations consist of 294 Massachusetts towns in 1988, with the insurance premium measured as the average price of a standard package of coverage. Their estimated equation using ordinary least squares is shown as equation (3.1) in Table 3. The variables all have the expected sign and are statistically significant. The insurance premium elasticity of -.57 is the key factor for evaluating the welfare consequences of rate regulation. A higher elasticity indicates that the demand for autos is more sensitive to insurance premiums, thus increasing the deadweight costs of mispricing insurance through rate regulation. As already discussed above, BZ find that the deadweight costs based on this equation are higher than the risk sharing or income redistribution benefits that rate regulation might confer.

We have estimated a comparable equation for California data, where the observations consist of 58 California counties in 1990 . The insurance premium variable available to us for California is not the same variable used in the Massachusetts study by BZ. The BZ insurance premium refers to a standard package of coverage, whereas the California insurance premium variable measures the average effective premium--the total auto premiums paid in 
each county divided by the number of insured cars. ${ }^{13}$ The estimated equation using ordinary least squares is shown as equation 3.2 in Table 3.

The California equation confirms the $\mathrm{BZ}$ conclusion regarding the insurance premium elasticity. Specifically, the insurance premium elasticity is of the same order of magnitude in California (-.63) as in Massachusetts (-.57), suggesting that the deadweight costs of auto premium regulation may alsc be of the same order of magnitude in the two states. ${ }^{14}$ The income elasticity in California is lower than in Massachusetts (.31 versus .48$)$, but remains statistically significant. The density variable (congestion cost) in California has an unexpected positive sign and is not statistically significant. This difference in congestion cost results between California and Massachusetts may depend on, among other factors, variations in the supply of public transportation across the two states.

In California, it is not enough to know how premiums affect the demand for insurance, because a large fraction of the population of drivers choose not to buy insurance (over $23 \%$ in 1985 (Table 2) and over $24 \%$ in our 1990 data set). We therefore must estimate separate elasticities for the demand for registered cars and the demand for insured cars. To assist in the interpretation of these elasticities, we provide a simple model of driver/insurance choice.

\section{B The Effects of Insurance Premiums on Uninsured Motorists}

Consider a specific motorist $i$. There will be a reservation premium $P_{i}^{*}$ below which the motorist will buy insurance; call this status I. In other words, for a given market premium $P$, if $P<P_{i}^{*}$, then $i \in I$. The reservation premium $P_{i}^{*}$ will vary among drivers, depending on individual characteristics.

When the market premium $P$ rises to or above $P_{i}^{*}$, the motorist will stop buying insurance. There are then two choices. He or she may no longer drive; call this status $\mathrm{W}$ 
(for walker). Or he or she may drive uninsured; call this status $\mathrm{U}$. The choice between $\mathrm{W}$ and $U$ will be determined by the relative costs of $W$ (the inconvenience of walking) and $U$ (the expected costs of driving uninsured), with individual drivers making different choices depending on their circumstances. However, whatever the choice made at $\mathrm{P}=\mathrm{P}_{\mathrm{i}}{ }^{*}$, the same choice will be made at $\mathrm{P} \succ \mathrm{P}^{*}{ }_{i}$, assuming that the factors determining the choice between $\mathrm{W}$ and $\mathrm{U}$ do not depend on $\mathrm{P}$.

The demand for insured cars per capita, I, will depend on, among other things, the premium $P$ relative to the distribution of the reservation premiums $P_{i}^{*}$ over the population. The higher the market premium $\mathrm{P}$, the lower $\mathbf{I}$, since more drivers will find that $\mathrm{P}$ exceeds their reservation premium. This determines the elasticity of the demand for insured cars per capita (variables are all in logs):

(3) $\quad I=a_{0}-a_{1} P, a_{1}>0$.

A comparable argument holds for the demand for uninsured cars per capita, $U$. The higher the market insurance premium, the higher the demand for uninsured cars. $U$ will also depend on other factors that determine the choice between driving uninsured and not driving at all. The dependence on $\mathrm{U}$ on $\mathrm{P}$ can be written:

(4) $U=b_{0}+b_{1} P, b_{1}>0$.

We should have $b_{1}<a_{1}$, since as individuals leave status I, some enter status $U$ but others enter status W. 
The total demand for registered cars per capita, R, is identically equal to the sum of I and U. (In our data set, all cars are assumed to be registered). The relationship between $\mathbf{R}$ and the market premium $P$ can then be determined by combining (3) and (4):

$$
\mathbf{R}=\mathbf{I}+\mathbf{U}=\left(\mathrm{a}_{0}+\mathrm{b}_{0}\right)-\left(\mathrm{a}_{1}-\mathrm{b}_{1}\right) \mathbf{P}=\mathrm{c}_{0}-\mathrm{c}_{1} \mathrm{P}, \mathrm{c}_{1}>0
$$

Thus, the registered car premium elasticity $c_{1}$ based on equation (5) should be lower than the insured car premium elasticity $a_{1}$ based on equation (3).

The total insurance premium $P$ does not take into account the additional information provided by the disaggregation of the premium into its component parts. Indeed our data set includes three insurance components: liability coverage for bodily injury and property damage $P_{L}$, comprehensive coverage $P_{C}$, and uninsured motorist coverage $P_{U}$. For insured drivers, each component should have a negative effect on the decision to drive a car, and the liability component $P_{L}$ should be the most important since (1) the risk of loss is greatest for this component and (2) a minimum amount of liability coverage is legally required.

For uninsured drivers, the liability and comprehensive components should also have negative effects on the decision to drive, because the premiums are a signal of the accident rate in each county and uninsured drivers should respond in the same way as insured drivers since the premiums represent the real risk of driving. The uninsured motorist premium, however, has two effects on the decision to drive, one positive and one negative. The negative effect arises because the uninsured motorist premium is a signal of accident costs just as it is for insured drivers. The positive effect arises because the uninsured motorist premium represents the expected value of liability claims that are avoided on average because uninsured drivers are "juilgement proof" (see Shavell [1986]). Consequently, the 
combined effect for insured and uninsured drivers of the uninsured motorist premium on the demand for registered cars should be smaller than for the other two insurance components.

\section{C Estimates of the Demand For Registered Cars}

We now consider empirical estimates of the above model. As the starting point, we have made two revisions in the California version of the $\mathrm{BZ}$ equation, which was shown above as equation 3.2. First, we now use population instead of households as the scaling variable for insured cars and income. Population data are likely to be more accurate than household data, and there is no obvious theoretical basis for preferring households to population as the scaling variable. Second, we replace the $B Z$ congestion variable $D$, which was estimated with the wrong sign for California data, with a measure of the percentage of the population using public transportation, denoted as $\mathrm{T}$.

There is the potential for simultaneous equation bias in estimating this model, since registered cars include uninsured cars, and larger numbers of uninsured cars may create higher insurance premiums (through the uninsured motorist coverage component). To correct for the correlation that might therefore exist between the error term and the insurance premium, we have estimated those equations in which the dependent variable is the demand for registered cars or uninsured cars with two stage least squares (TSLS). The supply side variables used as instruments include average miles driven per capita (MILES), accidents per capita (ACC), and the population density (D).

Equation (4.1) in Table 4 provides empirical estimates of equation (5) for the number of registered cars per capita. The constant, income $\mathrm{Y}$, and public transportation $\mathrm{T}$ terms correspond to the coefficient $c_{0}$ in equation (5). Compared with the specification in equation (3.2), the insurance premium elasticity $(-.51)$ is slightly lower, the income elasticity $(.51)$ is 
somewhat higher, and the goodness of fit $\left(R^{2}=.53\right)$ is substantially better. Furthermore, the public transportation variable $T$, which replaces the density variable $D$ in equation (3.2), is now statistically significant and has the expected negative coefficient, indicating that greater use of public transportation reduces the demand for registered autos.

The insurance premium $P$ used in equation 4.1 can be separated into its three coverage components, liability for bodily injury and property damage $P_{L}$, uninsured motorist $\mathrm{P}_{\mathrm{U}}$, and comprehensive $\mathrm{P}_{\mathrm{C}}$. Unfortunately, it proved impossible to estimate stable effects from the separate components because they are extremely highly correlated, as shown by the correlation matrix in Table 5. Consequently, we have been unable to test hypotheses concerning the individual premium components.

\section{D Estimates of the Demand For Insured and Uninsured Cars}

We next consider how car owners decide whether to be insured or uninsured drivers. We have carried this out in two forms. First, we have estimated the demand for insured and uninsured cars per capita, directly following the theoretical equations (3) and (4). Second, we have estimated the insured/uninsured decision using a logit estimator. The results are shown in Table 4.

Equation (4.2) in Table 4 provides empirical estimates of the number of insured cars per capita I, the empirical version of equation (3) (where the constant, income Y, and public transportation $T$ terms correspond to the coefficient $a_{0}$ ). The equation is estimated using ordinary least squares because the simultaneity bias is only present when the left hand side variable includes uninsured drivers. The income elasticity (.59) and the insurance premium elasticity (-.83) are both larger than the corresponding estimates in equation (4.1) for registered cars, in accord with the discussion of equations (3) and (5). 
Equation (4.3) in Table 4 provides empirical estimates of the number of uninsured cars per capita $U$, the empirical version of equation (4). The number of uninsured cars in each California county is computed as the difference between the number of registered cars and the number of insured cars. ${ }^{15}$ The estimated insurance premium elasticity is +.29 , indicating that higher insurance premiums create uninsured drivers. As expected, the insurance premium elasticity is also smaller than the absolute value of the elasticity in equation (4.2) for insured drivers, indicating that higher insurance premiums also cause some previously insured drivers to become non-drivers. Furthermore, the absolute value of the premium elasticity for uninsured cars in equation (4.3) is about one-third the premium elasticity in equation (4.2) for insured cars, indicating that the effect of higher premiums is split about one-fourth in creating uninsured drivers and three-fourths in creating non-drivers.

Since the number of registered cars is identically the sum of insured cars and uninsured cars, the premium elasticity in equation (4.1) for registered cars is close to the algebraic sum of the elasticities in equations (4.2) for insured cars and (4.3) for uninsured cars. If the estimated equations (4.1), (4.2), and (4.3) were linear, instead of log-linear, then the elasticity condition would be exactly satisfied. A logit estimator provides an alternative functional form in which this adding up constraint is exactly met (the log odds specification):

(6) $\log \left(\frac{\mu}{1-\mu}\right)=a_{0}+a_{1} Y-a_{2} T+a_{3} P$, where $\mu=\frac{U}{R}$ (= the ratio of uninsured cars to registered cars).

The estimated coefficients using TSLS are shown as equation (4.4) in Table $4 .{ }^{16}$ The income and public transportation elasticities are both negative, indicating that counties with 
either higher income or more public transportation have a lower ratio of uninsured drivers (although neither coefficient is statistically significant). The insurance premium coefficient is positive, large (1.1), and significant at the $10 \%$ level. When this premium coefficient is transformed at the point of the sample means to the form of an elasticity for the number of uninsured cars per capita, the result is .33 , very close to the directly estimated elasticity of .29 in equation (4.3). For simplicity, we will use the coefficient in equation (4.3) in later calculations. An equivalent equation can be estimated for the log odds of insured drivers, but the magnitude and statistical significance of the coefficients will be identical to those in equation (4.4) with the algebraic signs switched, since the log odds of uninsured drivers and the log odds of insured drivers sum identically to 0 .

\section{E The Effects of Insurance Premiums on the Assigned Risk Pool}

We next consider how insured car owners decide whether to purchase insurance through the voluntary market or the assigned risk pool. This decision was particularly important in California in the early 1990s, because the assigned risk pool premiums had been significantly suppressed during the late 1980s, creating a situation in which many drivers found the assigned risk pool premium to be lower than the corresponding premium in the voluntary market. (This situation was later rectified, resulting in a dramatic decline in the size of California's assigned risk pool during the early 1990s.) We thus expect the ratio of the voluntary market premium to the assigned risk premium to have a significant effect on the decision concerning in which market to purchase insurance.

We have carried out this estimation in two forms. First, we have estimated equations for the per capita number of cars insured through the voluntary market $V$ and assigned risk 
pool A, respectively. Second, we have estimated the voluntary market/assigned risk pool decision using a logit estimator. The results are shown in Table 6.

Equations (6.1) and (6.2) show per capita demand estimates for cars with voluntary insurance $V$ and assigned risk pool insurance $A$, where $V+A=I$ (total insured cars per capita). The insurance premium $\mathrm{P}_{\mathrm{V} / \mathrm{A}}$ is the ratio of the effective voluntary market premium for liability coverage $P_{v}$ and the effective assigned risk pool premium for liability coverage $\mathrm{P}_{\mathrm{A}} \cdot{ }^{17}$ The income and public transportation elasticities in both equations parallel the results for total insured cars in equation (4.2). The new factor here is the insurance premium ratio $P_{V / A}$, which, as expected, has a large, negative (-.72), and significant effect on voluntary market cars per capita and has a corresponding large positive (2.3) and significant effect on assigned risk pool cars per capita.

Equations (6.3) and (6.4) estimate a similar specification for the voluntary market and assigned risk insured cars per capita respectively, with the insurance variables for the voluntary market $P_{V}$ and assigned risk pool $P_{A}$ treated separately. In both cases, as expected, the own premium has a negative elasticity and the cross premium has a positive elasticity. Furthermore, the voluntary market premium coefficient is larger in absolute value than the assigned risk pool premium coefficient in both equations, indicating that a $1 \%$ suppression in both premiums would reduce the assigned risk pool by $0.6 \%$ and increase the voluntary market by $0.4 \%$. However, $\mathrm{F}$ tests at the $5 \%$ level indicate that we cannot reject the null hypothesis of equal elasticities for $P_{V}$ and $P_{A}$ in both equations (6.3) and (6.4).

A logit estimator provides an alternative functional form in which to estimate the choice between voluntary market and assigned risk insurance: 
(7) $\log \frac{v}{1-v}=a_{0}+a_{1} Y-a_{2} T+a_{3} \frac{P_{V}}{P_{A}}$

where $v=\frac{A}{I}$ (= the ratio of assigned risk pool cars to total insured cars).

The estimated coefficients are shown as equation (6.5) in Table 6. The income and public transportation elasticities are relatively small and not significant, indicating these factors do not play an important role in the choice between the two forms of insurance. The insurance premium ratio, however, has a large and highly significant coefficient, in line with the results in equations (6.1) to (6.4). Equation (6.6) estimates a similar log odds specification, with the two insurance premium terms separated. As in equations (6.3) and (6.4), the voluntary market premium $\mathbf{P}_{\mathrm{V}}$ has a larger effect than the assigned risk pool premium $\mathbf{P}_{\mathrm{A}}$, but $F$ tests cannot reject the null hypothesis of equal coefficients at the $5 \%$ level. In both equations (6.5) and (6.6), the implied insurance premium elasticities for the number of drivers insured per capita in the voluntary market and the assigned risk pool are very close to the corresponding elasticities in equations (6.1) to (6.4).

\section{F Summary of The Effects of Insurance Premiums}

In summary, our estimates for California auto insurance premium elasticities, based on a cross section of Califorinia's 58 counties, show large and significant effects in a variety of dimensions. At the most aggregated level, equation (4.1) indicates an insurance premium elasticity of -.51 for total registered cars. This is very close to the premium elasticity $(-.57)$ estimated in equation (3.1) by Blackmon and Zeckhauser [1991] for Massachusetts where they used insured autos as the dependent variable. This raises the question of what BZ would have found if they had used registered autos, instead of insured autos, as their 
dependent variable. It seems, however, this would not have changed their results in a substantive way because uninsured motorists are not important in Massachusetts (see Table 2).

In California, it is important to decompose registered cars into insured and uninsured cars. Equation (4.2) indicates a premium elasticity of -.83 for insured cars per capita and equation (4.3) indicates a premium elasticity of +.29 for uninsured cars per capita. Alternatively, the logit estimator in equation (4.4) indicates an insurance premium elasticity of .33 for uninsured cars per capita.

Insured cars in California can be further decomposed into voluntary market and assigned risk pool insurance. Using the ratio of the voluntary market premium to the assigned risk pool premium, equation (6.1) indicates an insurance premium elasticity of -.72 for voluntary market insured cars and equation (6.2) an elasticity of 2.3 for assigned risk pool cars. When the voluntary market premium and the assigned risk pool premium are estimated separately, (equations 6.3 and 6.4 ), the voluntary market premium receives a larger coefficient in absolute terms, although in each case an $\mathrm{F}$ test fails to reject the null hypothesis that the two insurance premium coefficients are equal in absolute value.

These results can be used to evaluate public policies that would suppress insurance. One such policy would be to suppress both the voluntary market and assigned risk pool premiums by $1 \%$. The lower premiums will reduce the number of uninsured drivers per capita by $0.29 \%$ (equation 4.1 ) and raise the number of insured drivers per capita by $.83 \%$ (equation 4.2). At the same time, the lower premiums may either leave the mix between voluntary market insurance and the assigned risk pool unchanged (equation 6.5), or create a shift away from the assigned risk pool (equation 6.6). 
The results can also be used to evaluate public policies in which only one or the other of the insurance premiums is suppressed. Suppressing either premium will reduce the number of uninsured drivers per capita and raise the number of insured drivers per capita, with the quantitative effect depending on the initial mix between voluntary market and assigned risk pool insurance. At the same time, suppressing the voluntary market premium alone will shift the mix away from the assigned risk pool, while suppressing the assigned risk pool premium alone will shift the mix toward the assigned risk pool.

The overall implication is that insurance regulation that suppresses premiums reduces the number of uninsured cars and possibly reduces the number of cars in the assigned risk pool. A reduction in the number of uninsured cars can be welfare enhancing for two reasons. First, the premiums or costs paid by insured motorists for losses created by uninsured motorists will fall. Second, those uninsured motorists who become insured motorists enjoy a welfare gain, because the decision to adopt insurance reveals their preference for the insured status. ${ }^{18}$ These benefits could be offset by a tendency for drivers to take less care when they switch from uninsured to insured status, although the evidence indicates that uninsured motorists actually have a higher accident frequency on average than insured motorists. ${ }^{19}$ A reduction in the assigned risk pool may be welfare enhancing due to the principal-agent inefficiencies that arise in such pools.

Overall, our estimates of the response of uninsured motorists to insurance premiums lends support to the view that insurance premium regulation, such as contained in Proposition 103, can be welfare enhancing. On the other hand, as with all regulation, the resulting deadweight losses have to be weighed against the possible benefits. 


\section{PROPOSITION 103}

We next consider the voting pattern on Proposition 103, the California voter referendum creating insurance regulation in California. Three special interest groups faced off in the campaign for auto insurance regulation: consumer activists, insurance companies, and trial lawyers. Each group had least one auto insurance referendum on the ballot: Proposition 100 by the California Trial Lawyers, Proposition 101 by Coastal Insurance Company, Proposition 103 by Ralph Nader and Voter Revolt, Proposition 104 by insurance industry (to create no-fault), Proposition 106 by insurance industry (to limit legal fees).

Campaigning for and against these propositions approached an intensity not seen since California's property tax initiative Proposition 13 which had occurred 10 years earlier. A poll of California attitudes with respect to the insurance propositions, taken several months before the election, asked the following ${ }^{20}$ :

"Overall, do you feel that the amount of money that the average person like yourself pays for automobile insurance is much too high, somewhat high or about right? "

If much too high or somewhat high: "Why do you think rates are so high?" (May indicate more than 1 category) 
Attitudes toward auto insurance were:

"Much too high" $\quad 77 \%$

"Somewhat high" $\quad 17 \%$

"About right" $4 \%$

The blame for high insurance rates was placed on:

The insurance industry ${ }^{21} \quad 45 \%$

Lawyers/the legal system $36 \%$

California drivers $\quad 38 \%$

To explore the motives of California voters further, we estimated regression equations to explain the voting record on Proposition 103 across California counties. In equation (7.1) of Table 7, the dependent variable is the log of the percentage voting yes (VOTE) on Proposition 103 and the independent variables are per capita income (Y) and the effective insurance premium (P), the same variables used in equation (4.1). There is a significant and positive relationship by county between higher insurance premiums and a yes vote on Proposition 103. The income relationship in equation (7.1), however, may just reflect the larger percentage of voters who own cars in high income counties, a relationship already confirmed in equation (4.1). Equation (7.2) verifies this hypothesis, since the number of insured cars per capita I is significant, while income is no longer significant.

A logit estimator provides an alternative functional form in which to estimate the voting choice: 
(8) $\log \frac{\tau}{1-\tau}=a_{0}+a_{1} Y+a_{2} P$

\section{where $\tau=$ the percentage voting yes.}

The estimates are shown as equation (7.3) in Table 7 and in equation (7.4) with the number of insured cars per capita added as an additional right hand side variable. The estimated coefficients reflect the same pattern evident in equations (7.1) and (7.2). When the premium coefficients are transformed at the point of the sample means to the form of an elasticity for the percentage voting yes on Proposition 103, the resulting elasticities are .63 for equation (7.3) and .98 for equation (7.4), both somewhat higher than the corresponding elasticities estimated in equations (7.1) and (7.2).

These results confirm the importance of high auto insurance premiums as a primary determinant of voting yes on Proposition 103. This leaves open, however, the question whether this voting behavior simply reflects self-interest--voters in high premium counties hoped Proposition 103 would lower their premiums--or a sentiment of fairness--voters sensed that their premiums were unfair relative to some reference standard. The fairness hypothesis receives some support from the fact that even in low premium counties, which stood to lose from premium compression, Proposition 103 received a substantial number of yes votes. On the other hand, Proposition 103 restructured premium setting and the administration of premium regulation in a number of other ways as well, so even voters in low premium counties may have expected to receive lower premiums as a result of Proposition 103.

In conclusion, we briefly comment on some of the directly observed effects of Proposition 103 since it was enacted 5 years ago. In the first place, the second tier of risk, the so called non-standard insurance contract has been eliminated. The fact that "take-all- 
comer" laws eliminate the second tier of contracts has been noted in a number of other states, e.g. Hawaii, Massachusetts, New Hampshire, North Carolina, and South Carolina, see Sloan and Githens [1994]. This, of course, raises the question of what happens to those customers who were previously in the second tier.

Secondly, although the intent of Proposition 103 was to limit risk classification to the three factors named in the Proposition, this has not happened and a number of other factors have been approved for use. Among these is zip-code, though now zip code is used in contiguous clusters, rather than the individual zip codes used previously. Obviously this does not eliminate the possibility that by crossing a street one's insurance rates could double, but it does reduce the number of boundaries at which this can occur.

What has changed, however, is the methodology used to calculate loss relatives. Insurance companies now estimate loss relatives sequentially, starting with a univariate estimation based on the drivers' safety record, then adding number of miles driven, and so on. Details of this procedure are sketchy, and how this affects premia in specific cases is not yet known.

\section{CONCLUSIONS}

The most important new result of this paper is the finding that a high insurance premium elasticity applies on the margin between insured/uninsured driving status. This means that insurance premium regulation, such as Proposition 103, may be welfare enhancing to the extent that it causes the percentage of uninsured motorists to decline. There is, however, an alternative strategy for lowering the percentage of uninsured motorists: the "Pay at the Pump" initiative which is likely to be forthcoming soon as a California referendum 
proposition. With pay at the pump, insurance premiums are collected primarily as a fee included in gasoline purchases. Since gasoline is needed to drive, pay at the pump eliminates all uninsured motorists.

In addition, we have confirmed the Blackmon and Zeckhauser (B\&Z) result that the demand for registered cars is highly premium elastic. In the context of Massachusetts' rate tempering, $B \& Z$ concluded that this high premium elasticity leads to welfare losses. In the case of rate compression, as in California, the high estimated premium elasticity, also leads to welfare losses, at least when categorization is costless.

Our results also point to the potentially important role of "fairness" with regard to insurance premium regulation. References to unfair insurance premiums were common in the campaign to pass Proposition 103. These references to fairness were successful because insurance companies find it difficult to document that high premiums reflect high expected costs, especially for drivers who rarely or never create accidents. It remains unclear, however, whether the importance of high insurance premiums as a determinant of yes votes on Proposition 103 reflects simple self-interest or true voter concern for fairness.

Although we have concentrated here on auto insurance, similar rate regulation questions arise in other areas of property and casualty insurance. For example, recent attempts by insurance companies to charge higher premia for hurricane insurance written on properties with close proximity to the ocean has met with strong consumer opposition. This practice is now widely called "shorelining" by obvious analogy with "redlining" in loan markets. Legislation against shoreline pricing will have the same effects on the availability of hurricane insurance that the legislation against territorial based pricing has on the availability of auto insurance. 
Earthquake insurance has recently become another area of major concern for casualty insurance companies in California. The recent Los Angeles earthquake has caused these companies and their reinsurance partners to reevaluate the expected costs of such insurance; some companies, in fact, now consider earthquake risks uninsurable. By law, however, insurance companies which provide homeowners insurance must also provide their customers the option to purchase earthquake insurance. This tie-in regulation has caused many companies to withdraw from the homeowners insurance market. This in turn has created a round of further regulatory moves against the insurance companies. It is particularly intriguing that in some cases the insurance companies have chosen not to provide earthquake insurance (and therefore homeowner's insurance) because they fear that earthquake premiums that would be high enough to protect the companies financially would be viewed by consumers as unfair. Thus, in this line of business also, questions of perceived fairness are preventing firms from offering contracts at the breakeven price, leading to a search for regulatory alternatives to the market. 


\section{BIBLIOGRAPHY}

All-Industry Research Advisory Council [1989], Uninsured Motorists.

Arrow, K.J. [1963], "Essays in the Theory of Risk-Bearing", Amsterdam, North Holland.

Best's Review [1990], "Property/Casualty Insurance Edition, vol 91, No. 1, May, p.16.

Blackmon, B. Glenn and Richard Zeckhauser [1991], "Mispriced Equity: Regulated Rates for Auto Insurance in Massachusetts," American Economic Review, May, 65-69.

Bond, Eric and Keith Crocker [1991], "Smoking, Skydiving and Knitting: The Endogenous Categorization of Risks in Insurance Markets with Asymmetric Information", Journal of Political Economy, vol. 99, no. 1, pp 177-199.

Borch, K. [1990], The Economics of Insurance, North Holland, Amsterdam.

Borenstein, Severin [1989], "The Economics of Costly Risk Sorting in Competitive Insurance Markets," International Review of Law and Economics," 9, 25-39.

Boyer, Marcel and Georges Dionne [1989], "An Empirical Analysis of Moral Hazard and Experience Rating," Review of Economics and Statistics, 71: 128-134.

Boyer, Marcel Georges Dionne, and Richard Kihlstrom [1989], "Insurance and the Value of Publicly Available Information," in Studies in the Economics of Uncertainty in Honor of Josef Hardar, edited by Thomas B. Fomby and Tae Kun Seo, New York: Springer-Verlag, 137-155.

California Counties Foundation [1991], 1991-1992 California County Fact Book.

California Department of Insurance, Rate Regulation Division [1978], Study of California Driving Performance by Zip Code (Phase 1).

California State Association of Counties [1991-1992], County Fact Book. 1991-1992 California.

Cooper, R. and B. Hayes [1987], "Multiperiod Insurance Contracts", International Journal of Industrial Organization, 5: 211-231.

Crocker, Keith and Arthur Snow [1986], "The Efficiency Effects of Categorical Discrimination in the Insurance Industry," Journal of Political Economy, Vol. 94, no. 21, p. 321-344.

Dahlby, G.B [1983], "Adverse Selection and Statistical Discrimination," Journal of Public Economics, 20, 121-130. 
D'Arcy, Stephen, P. and Neil A. Doherty [1990], "Adverse Selection, Private Information, and Lowballing in Insurance Markets," Journal of Business, Vol. 63, No. 2, 145-164.

Dionne, Georges and Neil Doherty [1992], "Adverse Selection in Insurance Markets: A Selected Survey," in G. Dionne editor, Contributions to Insurance Economics, Kluwer Academic Publishers.

Dudey, Paul O. [1991], "History of Consumer Activism as Respects the Insurance Industry" in The Impact of Consumer Activism on the Insurance Industry, p. 8, Society of CPCU.

Field Institute [1988], "The California Poll," Statistical Release \#1450.

Grabowski, Henry, W. Kip Viscusi, and William N. Evans [1989] "Price and Availability Tradeoffs of Automobile Insurance Regulation," Journal of Risk and Insurance, 56: 275-299.

Harrington, Scott E.[1992], "Rate Suppression," Journal of Risk and Insurance, 185-202.

Harrington, Scott E. [1993], "The Economics and Politics of Automobile Insurance Rate Classification," Journal of Risk and Insurance, Vol. 60 No. 1, 59-84.

Hoy, Michael [1982], "Categorizing Risks in the Insurance Industry," Quarterly Journal of Economics.

Hoy, Michael [1989] "The Value of Screening Mechanisms Under Alterative Insurance Possibilities", Journal of Public Economics, 39, 177-206.

Insurance Services Office (National Association of Independent Insurers [1988], Factors Affecting Urban Auto Insurance Costs.

Jaffee, D.M. and T. Russell [1993], "Fairness, Credit Rationing, and Loan Market Structure".

Jee, B. [1989], "A Comparative Analysis of Alternative Pure Premium Models in the Automobile Risk Classification System", Journal of Risk and Insurance, 56: 434-459.

Kahnemann, D., J. Knetsch, and R. Thaler [1986], "Fairness as A Constraint on Profit Seeking Entitlements in the Market," American Economic Review, pp. 728-741.

Keeton, William and Evan Kwerel [1984], "Externalities in Automobile Insurance and the Underinsured Driver Problem," Journal of Law and Economics, vol. XXVII (April).

Kimball, S.W. [1961], "The Purpose of Insurance Regulation: A Preliminary Inquiry in the Theory of Insurance Law," Minnesota Law Review, Vol. 45, 471-524.

Kuan, Jensen, and Raymond Peck, [1981], "A Profile of Uninsured Motorists in California," State of California, Division of Motor Vehicles. 
Kunreuther, H. and M. Patily [1985], "Market Equilibrium with Private Knowledge: An Example," Journal of Public Economics, 26, pp. 269-288.

Malinvaud, E.[1972], "The Allocation of Individual Risks in Large Markets", Journal of Economic Theory, 5: 312-328.

736

Miyazaki, H.[1977], "The Rat Race and Internal Labor Markets", Bell Journal of Economics, 8: 394-418.

National Association of Insurance Commissioners [1988], Report on Profitability by Line By State. 1981-1988.

Pindyck, Robert and Daniel Rubinfeld [1981], Econometric Models and Economic Forecasts, 2nd Edition, McGraw-Hill.

Puelz, Robert and Walter Kemmsies [1993], "Implications for Unisex Statutes and RiskPooling: The Costs of Gender and Underwriting Attributes in the Automobile Insurance Market", Journal of Regulatory Economics, 5: 289-301.

Radner, R.[1985], " Repeated Principal-Agent Games with Discounting", Econometrica, 53: 1173-1199.

Rea, Samuel A. Jr.[1992], "Insurance Classifications and Social Welfare," 377-396, in Georges Dionne editor, Contributions to Insurance Economics, Kluwer Academic Publishers.

Riley, J. [1979], "Informational Equilibrium", Econometrica, 47: 331-360.

Rosenfield, Harvey [1991], "Proposition 103: The Consumers Viewpoint" in The Impact of Consumer Activism on the Insurance Industry. Society of Property and Casualty Underwriters, p. 109.

Rothschild, M. and J. Stiglitz [1976], "Equilibrium in Competitive Insurance Markets", Quarterly Journal of Economics, 90: 629-649.

Rubinstein, A. and M.E. Yaari [1983], "Repeated Insurance Contracts and Moral Hazard", Journal of Economic Theory, 30: 74-97.

Shavell, S. [1986], "The Judgement Proof Problem," International Review of Law and Economics, 6, 45-58.

Sloan, F. and P.B. Githens [1994], "Drinking, Driving, and the Price of Automobile Insurance", Journal of Risk and Insurance, 61: 33-58.

Smith, Eric and Randall Wright [1992], "Why is Automobile Insurance in Philadelphia So Damn Expensive?" American Economic Review, Vol. 82, No. 4, 756-772. 
Spence, Michael [1973], "Job Market Signaling," Quarterly Journal of Economics, vol 87, 355 374.

State of California, Secretary of State [1988], Supplement to Statement of Vote. November 1988.

State of California [1991], Department of Finance, California Statistical Abstract.

Sugarman, Stephen D. [1990], "California Insurance Regulation Revolution: The First Two Years of Proposition 103", San Diego Law Review, Vol. 27, 683-714.

Sugarman, Stephen D. [1993], "Pay at the Pump", Auto Insurance, Institute of Governmental Studies Press, University of California, Berkeley.

Williams, G. [1992], "The Wiong Side of the Tracks", Territorial Rating and the Setting of Automobile Liability Insurance Rates in California", Hastings Constitutional Law Quarterly, 19: 846-909.

Wilson, C. [1977], "A Model of Insurance Markets with Incomplete Information," Journal of Economic Theory, 16: 167-207. 


\section{DATA APPENDIX}

All variables relate to the cross section of California's 58 counties and to the year 1990 , unless otherwise noted.

The variables I, R, U, A and V are stated on a per capita basis. Source of country population data: State of California [1991]. The variables are stated on a per household basis, and the number of households by county comes from the same source.

A Number of insured cars (per capita, full year equivalent policies) in the assigned risk pool. Source: California Department of Insurance.

ACC 1989 California accidents, California Counties Foundation [1991].

D Population/Miles ${ }^{2}$, State of California [1991].

I The number of insured passenger vehicles (per capita, full year equivalent policies). Source: California Department of Insurance.

MILES "Annual miles of travel per vehicle, California Counties Foundation [1991].

$\mathbf{P}_{\mathbf{V}} \quad$ Effective insurance premium, voluntary insurance companies. Source: California Department of Insurance.

$P_{A} \quad$ Effective insurance premium, assigned risk pool. Source: California Department of Insurance.

$\mathrm{P}_{\mathrm{V} / \mathrm{A}}=\mathrm{P}_{\mathrm{V}} / \mathrm{P}_{\mathrm{A}}$.

$\mathbf{P} \quad$ Effective insurance premium, weighted average of $\mathbf{P}_{\mathrm{V}}$ and $\mathbf{P}_{\mathrm{A}}$, the weights reflecting the percentage of total insured cars in each category.

$\mathrm{R}=\mathrm{I}+\mathrm{U}$. This variable includes all registered cars and $68 \%$ of registered trucks or light commercial vehicles (the percentage used for personal purposes).

$\mathrm{T} \quad$ Percent of residents journeying to work by public transportation, by California metropolitan areas, divided into counties for 1985 (latest year available). Counties without any indicated public transportation are set equal to the minimum value across the listed counties. Source: State and Metropolitan Area Data Book 1986, Bureau of Census, U.S. Department of Commerce.

U The number of uninsured vehicles (per capita). Source: California Department of Insurance.

$\mathrm{V}$ The number of insured cars (per capita, full year equivalent policies) in the voluntary insurance market. Source: California Department of Insurance. 
Y Per capita income. Source: State of California [1991].

VOTE Percentage of "yes" votes on Proposition 103. Source: State of California, Secretary of State [1988].

$\mu \quad=\mathrm{U} / \mathrm{R}$.

$\nu \quad=\mathrm{A} / \mathrm{I}$. 
Table 1

The Insurance industry achieves its profits by ...

$(\mathbf{n}=\mathbf{1 , 0 0 0})$

Overcharging for premiums

$65 \%$

Charging fair and adequate premiums and investing and managing

this money wisely

Undercharging for premiums, but making up the difference

through investments

Don't know

Companies that sell auto, homeowners and business insurance are ...

$\begin{array}{ccc}\text { Total } & \text { Male } & \text { Female } \\ (n=1,000) & (n=490) & (n=510)\end{array}$

Just as profitable as the companies in most other industries

$28 \% \quad 21 \% \quad 34 \%$

Less profitable than the companies in most other industries

5

More profitable than the companies in most other industries

Don't Know
61

6
5

71

3
5

52

9

Insurance companies that sell auto, homeowners and business insurance . . $(n=1,000)$

Strongly

Agree

Agree

Strongly

Mean*

Rating

Make a killing, but pretend they are not making money $35 \% \quad 32 \% \quad 25 \% \quad 5 \%$

Make a fair profit after expenses and loss payments

22

48

16

11

2.84

Make very little because their losses are always going up

2

8

48

39

1.73

* 4 = strongly agree, $3=$ agree, $2=$ disagree, $1=$ strongly disagree

Source: Best's Review [1990], p. 16. 


\begin{tabular}{||l|l|l||}
\hline \multicolumn{3}{|c||}{ Percentage of All Vehicles That are Uninsured } \\
(Based on Uninsured Motorist Claim Frequencies for 1985) \\
\hline State Rank & Státe & Percentage Uninsured \\
\hline 1 & Colorado & $30.3 \%$ \\
\hline 2 & Florida & 29.7 \\
\hline 3 & Alabama & 24.8 \\
\hline 4 & California & 23.3 \\
\hline 5 & Tennessee & 22.2 \\
\hline & & \\
\hline 46 & New York & 6.2 \\
\hline 47 & South Dakota & 5.9 \\
\hline 48 & Massachusetts & 5.8 \\
\hline 49 & Vermont & 5.1 \\
\hline 50 & North Carolina & 4.6 \\
\hline Source: All-Industry Research Advisory Council [1989] & \\
\hline
\end{tabular}

\begin{tabular}{|c|c|c|c|c|c|c|}
\hline $\begin{array}{r}\text { The } \\
\text { D }\end{array}$ & $\begin{array}{l}\text { mand fo } \\
\text { ndent } \mathrm{V} \\
\text { stimatio } \\
\text { (A }\end{array}$ & $\begin{array}{l}\text { sured } \\
\text { ble: Lo } \\
\text { Ordin } \\
\text { lute val }\end{array}$ & $\begin{array}{l}\text { Table } \\
\text {, Blackn } \\
\text { nsured } \\
\text { Least Sc } \\
\text { of T-stat }\end{array}$ & $\begin{array}{l}\text { and } \mathrm{Z} \\
\text { Per } \mathrm{H} \\
\text { res, All } \\
\text { es in pa }\end{array}$ & $\begin{array}{l}\text { lauser } \\
\text { ehold) } \\
\text { iables } \\
\text { heses) }\end{array}$ & $\begin{array}{l}\text { ification } \\
\operatorname{og}\left(I_{h}\right) \\
o g\end{array}$ \\
\hline Eqt. & State & C & $Y_{h}$ & D & $\mathbf{P}$ & $\mathbf{R}^{2}$ \\
\hline 3.1 & MA & N/A & $\begin{array}{l}.48 \\
(10.8)\end{array}$ & $\begin{array}{l}-.04 \\
(4.0) \\
\end{array}$ & $\begin{array}{l}-.57 \\
(4.8) \\
\end{array}$ & .59 \\
\hline 3.2 & $\mathrm{CA}$ & $\begin{array}{l}1.0 \\
(0.9)\end{array}$ & $\begin{array}{l}.31 \\
(2.5)\end{array}$ & $\begin{array}{l}.003 \\
(0.2)\end{array}$ & $\begin{array}{l}-.63 \\
(3.6)\end{array}$ & .26 \\
\hline
\end{tabular}


Table 4

The Demand for Autos and Auto Insurance in California

Observations: 58 California Counties in 1990

All Variables are in Log

(Absolute value of T-statistics in parentheses)

\begin{tabular}{||l|l|l|l|l|l|l|l||}
\hline Eqt & Est. & $\begin{array}{l}\text { Dep. } \\
\text { Var. }\end{array}$ & $\mathrm{C}$ & $\mathrm{Y}$ & $\mathrm{T}$ & $\mathbf{P}$ & $\mathrm{R}^{2}$ \\
\hline 4.1 & TSLS & $\begin{array}{l}\text { Registered } \\
\mathrm{R}\end{array}$ & $\begin{array}{l}4.8 \\
(4.4)\end{array}$ & $\begin{array}{l}.51 \\
(6.1)\end{array}$ & $\begin{array}{l}-.04 \\
(2.2)\end{array}$ & $\begin{array}{l}-.51 \\
(3.1)\end{array}$ & .53 \\
\hline 4.2 & OLS & $\begin{array}{l}\text { Insured } \\
\mathrm{I}\end{array}$ & $\begin{array}{l}5.7 \\
(4.1)\end{array}$ & $\begin{array}{l}.59 \\
(4.9)\end{array}$ & $\begin{array}{l}-.01 \\
(0.5)\end{array}$ & $\begin{array}{l}-.83 \\
(5.1)\end{array}$ & .45 \\
\hline 4.3 & TSLS & Uninsured U & $\begin{array}{l}1.2 \\
(0.4)\end{array}$ & $\begin{array}{l}.23 \\
(1.0)\end{array}$ & $\begin{array}{l}-.10 \\
(2.1)\end{array}$ & $\begin{array}{l}.29 \\
(0.6)\end{array}$ & .13 \\
\hline 4.4 & TSLS & $\begin{array}{l}\text { Log odds U: } \\
\mu\end{array}$ & $\begin{array}{l}-4.4 \\
(1.1)\end{array}$ & $\begin{array}{l}-.36 \\
(1.2)\end{array}$ & $\begin{array}{l}-.09 \\
(1.4)\end{array}$ & $\begin{array}{l}1.1 \\
(1.8)\end{array}$ & .17 \\
\hline
\end{tabular}

See data appendix for symbol definitions and data sources.

\begin{tabular}{|c|c|c|c|c|}
\hline \multicolumn{5}{|c|}{ Correlation Matrix, Insurance Premium Components } \\
\hline & $\mathbf{P}$ & $\mathbf{P}_{\mathbf{L}}$ & $\mathbf{P}_{\mathrm{U}}$ & $\mathbf{P}_{\mathrm{C}}$ \\
\hline Total Premium $\mathbf{P}$ & 1.00 & .99 & .94 & .83 \\
\hline Liability Coverage $P_{L}$ & .99 & 1.00 & .92 & .75 \\
\hline $\begin{array}{l}\text { Uninsured Motorist } \\
\mathbf{P}_{\mathbf{U}}\end{array}$ & .94 & .92 & 1.00 & .77 \\
\hline Comprehensive $\mathrm{P}_{\mathrm{C}}$ & .83 & .75 & .77 & 1.00 \\
\hline
\end{tabular}




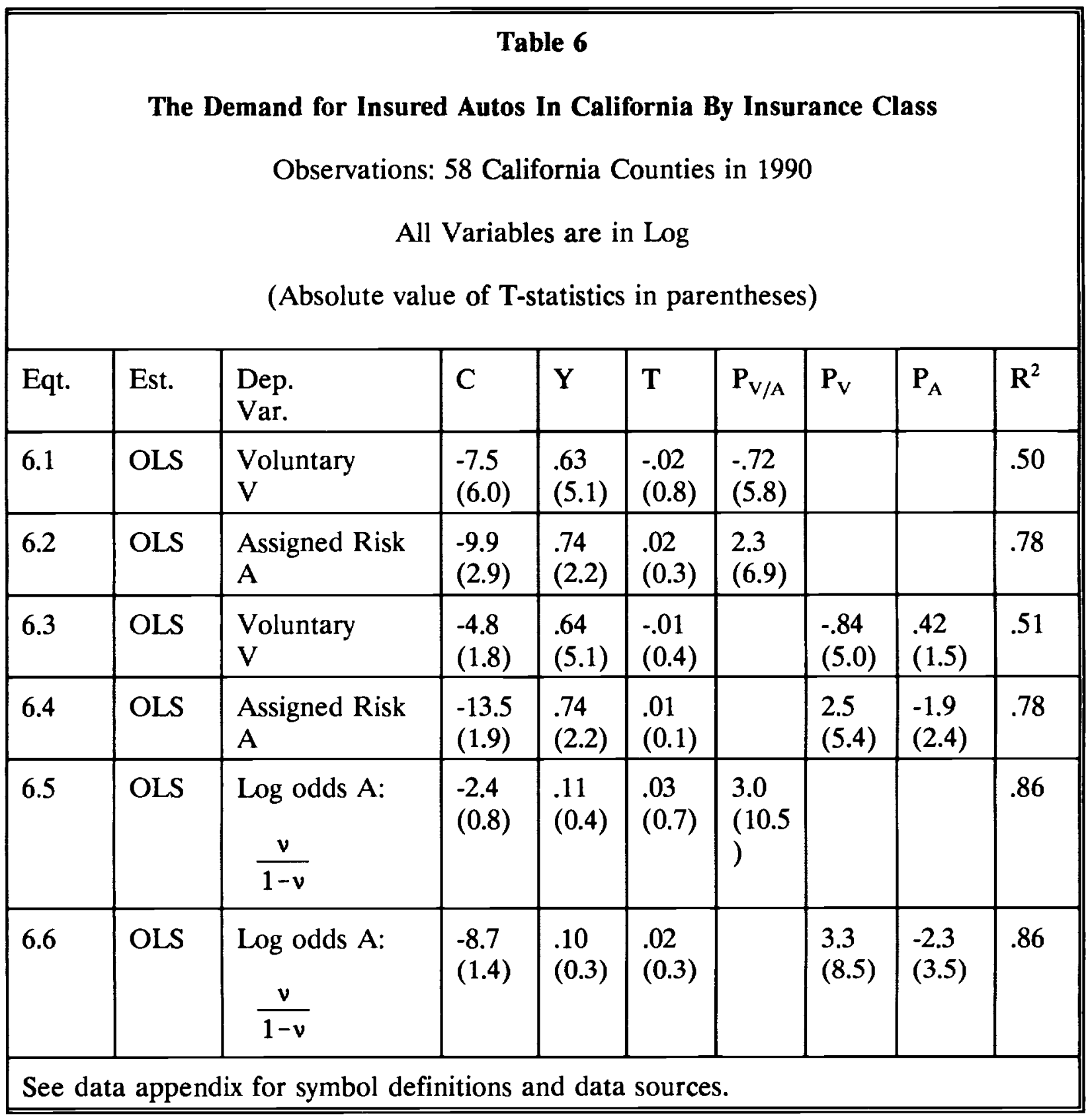




\begin{tabular}{|c|c|c|c|c|c|c|}
\hline & $\begin{array}{r}\text { Obs } \\
\text { Estimation by } \\
\text { (Absolut }\end{array}$ & $\begin{array}{l}\text { Tal } \\
\text { ropositiol } \\
\text { tions: } 58 \\
\text { lary Leas } \\
\text { ue of T-S }\end{array}$ & $\begin{array}{l}\text { le } 7 \\
103 \text { Vo } \\
\text { aliforni } \\
\text { Squares } \\
\text { atistics }\end{array}$ & $\begin{array}{l}\text { ountie } \\
\text { dl Vari } \\
\text { Parentr }\end{array}$ & es in $\mathrm{L}$ & \\
\hline Eqt. & Dep. Var. & $\mathrm{C}$ & $\mathbf{Y}$ & $\mathbf{P}$ & I & $\mathbf{R}^{2}$ \\
\hline 7.1 & VOTE & $\begin{array}{l}-3.4 \\
(4.4) \\
\end{array}$ & $\begin{array}{l}.36 \\
(3.5)\end{array}$ & $\begin{array}{l}.58 \\
(4.5) \\
\end{array}$ & & .62 \\
\hline 7.2 & VOTE & $\begin{array}{l}-6.2 \\
(6.2)\end{array}$ & $\begin{array}{l}.10 \\
(0.9)\end{array}$ & $\begin{array}{l}.98 \\
(6.3)\end{array}$ & $\begin{array}{l}.45 \\
(3.9)\end{array}$ & .71 \\
\hline 7.3 & $\begin{array}{l}\text { Log odds Vote: } \\
\frac{\tau}{1-\tau}\end{array}$ & $\begin{array}{l}-12.8 \\
(10.3)\end{array}$ & $\begin{array}{l}.61 \\
(3.7)\end{array}$ & $\begin{array}{l}1.1 \\
(5.0)\end{array}$ & & .67 \\
\hline 7.4 & $\begin{array}{l}\text { Log odds Vote: } \\
\frac{\tau}{1-\tau}\end{array}$ & $\begin{array}{l}-17.1 \\
(10.2)\end{array}$ & $\begin{array}{l}.22 \\
(1.2)\end{array}$ & $\begin{array}{l}1.7 \\
(6.5)\end{array}$ & $\begin{array}{l}.68 \\
(3.5)\end{array}$ & .73 \\
\hline
\end{tabular}




\section{ENDNOTES}

1. The authors would like to thank the participants in seminars at which earlier versions of this paper were presented, particularly David Bradford, Georges Dionne, Patricia Danzon, Louis Eckoud, Fred Furlong and Sean Mooney for their helpful comments. We would also like to thank Ashok Bardhan for excellent research assistance.

2. A brief history of early developments with further references may be found in Kimball [1961].

3. In many states, the law directs the insurance commissioner to eliminate "unfair and discriminatory pricing practices". P.O. Dudey [1991] claims that "among the more severe criticisms of the insurance industry is the inequity of the ratings methods used, particularly, but by no means exclusively, in auto insurance."

4. A California Department of Insurance study noted that every insurance company in California which wrote automobile liability insurance in 1978 used place of residence in setting its rates. See California Department of Insurance, Rate Regulation Division [1978].

5. Assigned risk plans differ across states in the details of their operation, but the general principal is that the companies operating in the standard market share the losses of the assigned risk pool.

6. Cal. Ins. Code \#1861.05(a) (West Supp. 1990) as cited by Sugarman [1990].

7. Of course, insurance companies use deductible limits and other forms of non-linear 
pricing, but it appears to us that these reflect cost considerations and are not used to induce individuals to self-select specific contracts.

8. When we use the word "fairness" we should stress that we mean "perceived fairness". As economists, we are not endorsing these reported dimensions of fairness as being in any welfare sense fair or just.

\section{Source: Insurance Services Offices [1988].}

10. A rapid growth in auto insurance fraud may be one explanation for the rapidly rising premiums. It has been suggested that the companies took action to control fraud following the passage of Proposition 103, with the result that their claim losses fell.

11. Because so many features of the automobile insurance industry seem compatible with competition, we will proceed on this premise.

12. Again, note that we are assuming that the probability of an insured motorist being in an accident with an uninsured motorist reflects only the proportions of the two types of drivers. If uninsured motorists have a higher tendency to have accidents with each other, then our conclusion need not follow.

13. The insurance premium data for California counties in 1990 were obtained from the California Department of Insurance. The premiums include three components, liability coverage for bodily injury and property damage, uninsured motorist coverage, and comprehensive coverage. The liability component is a weighted average of the premium paid in the voluntary insurance market and for the assigned risk pool. 
14. The slightly higher estimated elasticity in California may arise because insurance premiums (California) vary less than standard coverage premiums (Massachusetts).

15.This measure will miss uninsured vehicles that are also unregistered. This becomes a serious problem, however, only if the percentage of all vehicles that are uninsured and unregistered varies significantly across counties.

16. The general conditions discussed in Pindyck and Rubinfeld [1981], pp. 289-295, under which reliable coefficient estimates of logit specifications can be obtained without maximum likelihood estimators, are satisfied in our application.

17. We could obtain reliable estimates for the effective insurance premiums in the assigned risk pool by California counties only for bodily injury and property damage liability coverage. Consequently the premiums PV and PA and their ratio are based only on this component of the auto insurance coverage.

18. The welfare benefits of decreasing the percentage of uninsured motorists are discussed at greater length in Smith and Wright [1992].

19. The statistics tabulated in Kuan and Peck [1981] found that compared to the average California driver, the uninsured driver had (1) a much worse prior accident record and (2) a much worse prior traffic conviction record. Of course, this does not necessarily mean that driving habits change when a driver changes his/her status from uninsured to insured.

20. See the Field Institute [1988].

21. Specific responses included: 
"Insurance companies are greedy" $\quad 22 \%$

"Insurance companies are unregulated" $\quad 13 \%$

"Insurance companies make too much money" $12 \%$ 